\title{
Intellectual Property Rights, Investment Climate and FDI in Developing Countries
}

\author{
Samuel Adams \\ Ghana Institute of Management and Public administration \\ P.O. Box AH 50, Achimota, Accra-Ghana \\ Tel: 23-320-332-5272_E-mail: sadamss2000@yahoo.com
}

\begin{abstract}
What is the impact of intellectual property rights (IPR) protection on foreign direct investment (FDI)? Has the coming into effect of the Agreement on Trade Related Aspects of Intellectual Property Rights (TRIPS) had any impact on FDI inflows in developing countries? This paper answers these questions by the use of panel data for a cross - section of 75 developing countries over a period of 19 years $(1985-2003)$. The results of the study indicate that: 1) strengthening IPR has a positive effect on FDI; 2) the impact of patent protection on FDI after the TRIPS agreement is far and above that of the pre - TRIPS era; 3 ) the degree of openness, growth rate of the economy and investment are also key determinants of FDI. The findings of the study suggest that strengthening IPR is only one component of the many factors needed to maximize the potential of developing countries to attract FDI.
\end{abstract}

Keywords: Intellectual property rights, Foreign direct investment, Investment climate, Risk, Developing countries

\section{Introduction}

Intellectual property rights (IPR) reform has been underway since the 1990s and actively pursued by most developing countries after the World Trade Organization's (WTO) Agreement on Trade Related Aspects of Intellectual Property Rights (TRIPS) came into effect on January 1, 1995 (Commission on Intellectual Property Rights [CIPR], 2002). Under the terms of TRIPS, current and future members of WTO must adopt and enforce strong non-discriminatory minimum standards of intellectual property protection in each of the areas commonly associated with IPRs including patents, copyrights, trademarks, and trade secrets. Beyond strengthening of IPR, the TRIPS Agreement is the first multilateral trade accord that aims at achieving partial harmonization in an extensive area of business regulation, as it seeks to establish deep integration of domestic regulatory policies across countries (Maskus, 2000a).

Advocates of IPR have promoted its strengthening, in part, by underscoring the incentives that IPR generate for innovation and its real world application (Lippoldt, 2006). Obviously, the strengthening of IPR globally benefits the developed nations who own most of the intellectual property, however, developing countries are also expected to benefit in terms of FDI and technology transfer where there is an incentive to disseminate and share in the benefits of Research and Development (R \& D) (Asid et al., 2004).

IPR has therefore become part of the infrastructure supporting investments in Research and development that are important in innovation and new business development. By granting temporary exclusive rights on inventions, IPR allows the right holders to price their products above marginal cost, and hence recoup their initial research investment costs (Leger, 2006). Accordingly, the creation of an effective IPR regime has an effect not only on the incentive for new knowledge creation and its dissemination, but even more importantly the business location decision of firms, prices, and the market structure. Kalande (2002), for example, noted that most multinational enterprises (MNEs) are willing to invest in non-manufacturing sectors or extractive industries rather than invest in technology intensive activities in countries with inadequate IPR protection. Similarly, Nicholson (2002) claimed that an enhanced IPR protection encourages firms to undertake overseas production due to the expanded protection of their ownership advantages.

Understanding how FDI inflows are impacted by IPR is important because many studies do show that FDI plays an important role in the development process (Kalande, 2002). Apparently, the flow of FDI to developing countries in the right sectors of the economy would provide these countries with the opportunity to benefit from technological change. The Global Development Finance (2005) indicates that FDI has become one of the stable sources of development finance in developing countries. For instance, by the end of 2004, the total foreign aid (grants) and net official flows (aid and debt) to developing countries were $\$ 47.4$ billion and $\$ 22.6$ billion respectively, while net FDI flows was $\$ 165$ billion dollars. UNCTAD report (2003) indicates that the emergence of Botswana from a least developed country into a middle - income country status between one generation was 
mainly driven by the influx of FDI; an effect which is unmatched by any other country of similar size or level of economic development.

The objective of this paper is to examine the impact of IPR on FDI inflows for 75 developing countries between 1985 and 2003. The period was chosen to help to identify not just the impact of IPR, but also to examine whether the coming into effect of the TRIPS agreement in 1995 have had any effect on FDI inflows. It is important to note that the study's sample is made up of only developing countries as most studies have shown differential effects of IPR on FDI for developing and developed countries (Seyoum, 1996; Park and Lippoldt, 2003; Kalande, 2002; Falvey et al., 2006). The study also examines how other important factors like political and economic risk, return on investment, growth rate, and trade affect the inflow of FDI in developing countries.

The rest of the paper is organized as follows: Section 2 reviews both the theoretical and empirical literature on the IPR-FDI relationship. Section 3 presents the empirical methodology and data used in the analysis and Section 4 presents and discusses the results of the study. Section 5 offers policy implications, directions for future research, and concluding remarks.

\section{Literature Review}

Supporters of a strong IPR system attribute its importance to its double function of promoting innovation and FDI inflows, which are important determinants of growth. This is because strong IPR encourages holders of intellectual property to trade and invest, as adequate protection of IPR assure foreign investors that their technology will not be leaked to competitors. As a result, the smaller risk of imitation leads to a larger net demand for protected products (Mansfield, 1994; Seyoum, 2006). A country that enhances its IPR regime may attract additional knowledge intensive products, which will otherwise be unavailable on the local market or it may attract FDI; in either case, international technology transfer is likely to flow (Lippoldt, 2006).

To further understand how property rights protection affects a firm's decision to invest abroad, it is useful to appreciate the economic incentives firms have in investing abroad or becoming multinational. The most widely accepted framework in this regard is Dunning's (1981) OLI model. Dunning's (1981) OLI paradigm explains the activities of multinational enterprises (MNEs) in terms of ownership (O), Location (L), and internalization (I) advantages. The ownership advantages are generally intangible assets in the form of superior technology, organizational skills, trademark, trade secrets, patent, reputation, and innovative capacity, which other firms do not have. Such advantages confer market power and costs efficiencies that provide incentives to undertake multinational organization and operation (Maskus, 1998).

However, ownership advantages by themselves are not enough for overseas investment because many firms that possess intangible assets may choose to serve foreign markets by arm's length trade relationships (Braga and Fink, 1998). Even with ownership advantages, MNEs must still decide on where to invest. These decisions depend on the country conditions or characteristics, called the location advantages, which include factors like market size, transportation and communication infrastructure, skilled labor and favorable local government regulatory environment. Such advantages make it profitable to locate a business abroad. This means that FDI is not only "pushed" by firm specific advantages of the investor but may also be "pulled" to locations that are important sites of innovation activities (Seyoum, 2006). Further, it might be more profitable for the firm to internalize production rather than license or export goods on the open market. By being able to exploit their knowledge-based assets (KBA) within the confines of international operations, firms are able to overcome the high transaction costs associated with regulating and enforcing contracts and protecting quality (Braga and Fink, 1998; Maskus, 1998; Smarzynska, 2004). Thus, internalization explains why a foreign firm prefers to retain full control over the production process or try to acquire a subsidiary rather than license its intangible assets to local firms or an independent foreign firm.

The discussion above shows that firms that create intellectual property are less likely to engage in foreign production in countries with an inadequate IPR regime. This is because weak IPR protection increases the probability of imitation and risk of the licensee acting in direct competition with the seller. Park and Lippoldt (2005) argued that intellectual property owners will have weak incentives to market their technologies in developing regions with poor IPR regime due to risks of infringement.

On the other hand, a strong IPR system could provide knowledge based firms with market power and might actually cause firms to divest and reduce their services to foreign countries (Braga and Fink, 1998). Furthermore, a strong IPR system may have a negative effect on FDI, as it might encourage MNEs to shift from local production to licensing. Also, the ways in which IPR influence FDI are multifaceted and strong IPR alone is not adequate for firms to invest in a country. If they were, large amounts of FDI would have gone to Eastern Europe and Sub-Saharan Africa. On the contrary, China, Brazil, and other high-growth, large market developing countries with weak protection have attracted most of the FDI to developing countries (Maskus, 2000b). The net effect of higher levels of IPR protection on FDI is thus theoretically ambiguous. The inability to make strong 
qualitative predictions stems from the fact that a firm's decision to invest stems not only from the efficiency of patent protection, but also the interplay of market power, free riding, contracting uncertainties, and other features of the international markets for information (Maskus (2000a). It is therefore not surprising that in recent times some empirical studies have been done to ascertain the relationship between the protection of intellectual property and FDI.

Like the theoretical studies, the empirical studies have also given inconsistent results. While Lesser (2002), Lee and Mansfield (1996), and Smarzynska (2004) found a positive effect of IPR on FDI, Kondo (1995), Nicholson (2007), and Seyoum (1996) reported otherwise. Based on a survey of patent attorneys and licensing executives, Lesser (2002) used a cross sectional design to examine the relationship between IPR and FDI for a sample of 44 developing countries and found that strong property right protection was positively associated with FDI inflows. Similarly, Smarzynska (2004) used 1995 data to study the impact of IPR on FDI inflows in Eastern European countries and reported that weak IPR deterred FDI and rather encouraged investors to focus on distribution of imported products.

However, an investigation of the interaction of industry characteristics and IPR on multinational firm behavior by Nicholson (2007) showed that firms in industries with high capital costs are more likely to maintain control over production knowledge in countries with less IPR protection by engaging in FDI. Moreover, Nicholson (2007) reported that when IPR is strong, firms with high investment in R\&D are more likely to enter a market by licensing to an unaffiliated host firm. Smith (2001) also found that strong positive effect of IPR on both FDI and licensing, while Park and Lippoldt (2005) reported that developing countries that have moved to improve their IPR system have tended to experience enhanced access to technology through licensing. Clearly, the decision to trade, undertake FDI, or license is a complex process, which is affected by many decision criteria and therefore different firms choose different modes of entry due to their relative sensitivity to protection. Firms with natural barriers to imitation tend to choose licensing, and vulnerable firms choose FDI, but stronger IPR may cause substitution between these modes (Nicholson, 2007).

On the other hand, Seyoum (1996) studied 27 countries from 1975 to 1990 and demonstrated that patent protection was positively correlated with FDI inflows in developed but not in less developed countries. Likewise, Kondo (1995) analyzed the flow of US FDI to 33 European, Asian and Latin American countries between 1976 and 1990 and found patent protection to be insignificantly correlated with FDI inflows. Though Kondo's (1995) study sample was made up of developed countries, the author claimed that there was no evidence that patent protection facilitated FDI and suggested that the least developed countries should be aware of the study's results.

Nonetheless, Park and Lippoldt (2003) argued that the earlier studies do not capture the benefits of the TRIPS agreement, which came into effect in 1995. As a result, they used data (between 1990 and 2000) that captures the post TRIPS agreement and found that strengthening IPR has a positive effect on FDI inflows. However, they also noted that IPR's effect is dependent on the level of development and other relevant unobserved country-specific characteristics (e.g., culture and quality of institutions). In addition, Park and Lippoldt (2003) showed that IPR's effect was largest in the least developed countries and second largest in developing nations (where IPR regimes are next weakest). This finding is consistent with the view that IPR's effect on FDI is influenced by a country's level of development.

The review of the empirical literature indicates that the effect of IPR on FDI is influenced by data heterogeneity, observed and unobserved country-specific effects, and the TRIPS agreement. Accordingly, we control for these factors in our analysis of the impact of IPR on FDI by using a panel data set of developing countries over the period 1985 - 2003. This period allows us to identify the differential effects, if any, of IPR on FDI before and after the TRIPS agreement came into effect in 1995. The data and empirical methodology used are described below.

\section{Data and Methodology}

The data for the study comes from various sources. The data on FDI inflows comes from the World Development Indicators CD - ROM (2006), and is measured as the net FDI inflows share in GDP. The net FDI are the net inflows of investment to acquire a lasting management interest (10\% or more of voting stock) in an enterprise other than that of the investor. This is the sum of equity capital, reinvestment of earnings, other long-term capital, and short-term capital as shown in the balance of payments. The strength of intellectual property rights protection (IPR) is measured by the Ginarte - Park index of patent rights, which is based on five categories of patent laws: (1) extent of coverage, (2) membership in international patent agreements, (3) provisions for loss of protection, (4) enforcement mechanism, and (5) duration of protection. Each of these categories (per country, per time period) is scored a value ranging from 0 to 1 , and the outweighed sum of these five values constitutes the overall value of the patent rights index. The index therefore ranges from 0 to 5 , with higher numbers indicating stronger protection. 
Data on Real GDP per capita growth rate (ARG) and real GDP per capita were obtained from World Economic Outlook (2000) and Global Development Network Growth Database. Data on inflation, openness, population, and mainline telephone per 100 people (Tel) were obtained from the Global Development Network Growth Database. Openness (OPEN) is a measure of the level of integration into the world economy and is measured as trade (exports plus imports) as a percentage of GDP and the rate of inflation (INF) is used as a proxy for macroeconomic stability. Population (POP) is used as a measure of market size and mainline telephone per 100 people represents the level of infrastructure development. Return on investment (ROI), which is a measure of profitability is proxied by the inverse of GDP per capita (Asiedu, 2002; Nganga, 2005; Naude and Krugell, 2003). This is based on the assumption that investments in countries with a lower per capita income should yield a higher rate of return.

The risk variable (RISK) is a composite measure of the investment climate, which is obtained from the Political Risk Services' Country Risk Guide. It is made up of three measures: political, financial, and economic risk and it includes factors like law and order, government stability, bureaucratic quality and corruption. It is rated on a scale of zero to 100 , with zero meaning highest risk and 100 referring to the lowest risk. The average FDI and IPR for the countries in the study sample are listed in Tables 1 and 2.

Insert Table 1, Table 2 Here.

\section{Model Specification}

The empirical analysis is based on a panel data set consisting of four separate 5-year periods (the last period is 4 years), 1985-1989, 1990-1994, 1995-1999, and 2000-2003. All variables represent the average over the sub-periods, except the IPR variable, for which we use the initial values because it is assumed that it takes time for the IPR reform to have an effect on FDI inflows. The equation we estimated is specified as follows:

$$
\begin{gathered}
\mathrm{FDI}=\beta_{0}+\beta_{1} \mathrm{ARG}_{\mathrm{it}}+\beta_{2} \mathrm{OPEN}_{\mathrm{it}}+\beta_{3} \mathrm{INF}_{\mathrm{it}}+\beta_{4} \mathrm{LGPOPit}+\beta_{5} \mathrm{ROI}_{\mathrm{it}}+\beta_{6} \mathrm{RISK}_{\mathrm{it}}+ \\
\beta_{7} \mathrm{Tel}_{\mathrm{it}}+\beta_{8} \mathrm{IPR}_{\mathrm{it}}+\beta_{9} \text { IPRSQ }_{\mathrm{it}}+\beta_{10} \text { IPR }^{*} \mathrm{TRIPS}_{\mathrm{it}}+\mu_{\mathrm{i}}+\varepsilon_{\mathrm{it}}
\end{gathered}
$$

where, i signifies a country in year $t ; \beta_{0}$ is the constant term; $\beta_{\mathrm{i}}$ s are the coefficients to be estimated; $\mu_{\mathrm{i}}$ represents the country-specific effect which is assumed to be time invariant, and $\varepsilon_{\mathrm{it}}$ is the classical disturbance error component. In addition to the variables explained earlier, the square of IPR (IPRSQ) is included to capture any nonlinear relationship between IPR and FDI; and TRIPS represent the TRIPS dummy (1 for post TRIPS era and 0 otherwise) and the interaction of IPR and TRIPS dummy (IPR*TRIPS) is included to examine whether there is a differential effect of IPR before and after the TRIPS agreement came into effect in 1995.

We estimate a system of four equations using the seemingly unrelated regressions (SUR) method. The SUR estimation allows for different error variances in each equation and for correlation of these errors across equations (Makki and Somwaru, 2004). To eliminate any country - specific effects or unobserved heterogeneity we first - differenced the data. To further eliminate or reduce heteroscedasticity problems we used SUR with cross section weights.

\section{Results}

The purpose of our study is to analyze the effect of IPR on FDI inflows and to determine whether the TRIPS agreement that came into effect in 1995 has any effect on FDI inflows in developing countries. The equation is estimated by seemingly unrelated Regressions (SUR) in order to exploit interrelationships among the equations. The regression results are reported in Table 3 . The results show that the IPR variable is significant and positively correlated with FDI at the $1 \%$ and $5 \%$ levels respectively (Columns 3 and 5). The study's findings contradict the earlier studies of Seyoum (1996) and Kondo (1995), which suggest that patent protection does not promote FDI inflows to developing countries. These two studies' time periods were in the late 1980s and early 1990s when IPR in these countries were relatively low as seen in Table 2

Table 2 shows the average IPR for both 1985 and 1990 was 2.14, but this increased to 2.43 in 1995 and 2.83 in 2000 after TRIPS agreement. Thus, it could be argued that the IPR levels of most countries had not reached the necessary threshold needed to impact FDI inflows. This is to some extent supported by the study's finding as indicated by the IPR*TRIPS cross - product (Column 5), which suggests that IPR's effect on FDI in the post TRIPS era (after 1995) is far and above the pre-TRIPS period (before 1995). Clearly, the TRIPS agreement, which came into effect in 1995 led to the strengthening of IPR in most developing countries and subsequently led to a significant increase in FDI for most developing countries. As shown in Table 2, the average FDI share in GDP increased from just about $1 \%$ in 1985 to an average of $3.16 \%$ between 2000 and 2003 . It is also important to note that in a recent study, Seymour (2006) reported a significant positive effect of patent protection on FDI, although the study's sample was made up of both developed and developing countries.

Insert Table Here 
Additionally, we tested for nonlinear effects of IPRs on FDI by including the power term of the patent protection variable (IPRSQ). The results show that both IPR and IPRSQ are positive but not significant and hence, unlike the Asid et al.'s (2004) study, we do not find support for a nonlinear relationship or diminishing returns of IPR on FDI for developing countries as a whole. It is important to note that the Asid et al.'s (2004) study examined the period between 1996 and 2000 and the sample was made up of both developed and developing countries, and thus, it can be argued that the presence of threshold effects could be sensitive to the type of countries included in the analysis.

Growth rate is positive and significantly correlated with FDI, which is consistent with the findings of Kobrin (2005) and Nunnenkamp (2002) that showed that the growth rate of an economy, which is an indication of the market growth and potential, is an important determinant of FDI. The degree of openness is positive and significantly correlated with FDI at the $5 \%$ and $1 \%$ level in various specifications of the model (Columns 1 through 5). The findings reported here support Chakrabarti (2001) and Morisett's (2000) argument that openness to trade has a greater likelihood to be correlated with FDI inflows than any other variable.

Both population and inflation are not significantly correlated with FDI. Return on investment is positive and significantly correlated with FDI. Obviously, strengthening IPR allows firms to be better able to appropriate a return on their technological investments and therefore they have greater incentive to promote local production in those markets. The risk variable, which is a measure of the investment climate, is positive and significantly related with FDI at the $1 \%$ level in all the model specifications, which implies that the investment climate is one of the most important determinants of FDI inflows. This finding is consistent with Nunnenkamp and Spatz's (2003) claim that country-specific conditions may be more important than IPR per se in attracting FDI, and it is also likely to influence the IPR-FDI relationship.

Telephone mainline per 100 people is negative but insignificantly correlated with FDI inflows. This could be due to the fact that the communications infrastructure of most developing countries has not reached the necessary threshold required to positively affect FDI inflows. For instance, the average mainline telephone for Sub-Saharan Africa (SSA), which makes about $40 \%$ of the study's sample, is only 1.5 per 100 people (World Development Report, 2004). Thus, Manhattan has more telephones than the whole of Africa (Kenny and Keremane, 2007). It is not surprising that SSA ranks higher than other developing countries in terms of their IPR, yet they receive the least FDI.

\section{Policy Implications}

The study's results show that IPR and other social, economic, and institutional factors influence the inflow of FDI into developing countries. Also, the strengthening of IPR in most developing countries has resulted in an increase in FDI inflows. These results have important policy implications. First, developing countries are likely to benefit from the reform of their intellectual property system at the least in terms of increased FDI inflows. Nevertheless, the means by which IPR influences FDI is subtle and complex, and therefore strong IPR alone does not sufficiently generate the desired incentives for firms to invest in a foreign country. Obviously, if that were the case, most FDI inflows to developing countries would have gone to SSA. In contrast, China and other high growth, large market developing countries with weak IPR have received the bulk of FDI in recent years. Thus, from a policy perspective, IPR reform must be accompanied by proactive policies that encourage improvements in physical and institutional or governance infrastructure, and business climate to improve the chances of attracting more FDI (Dunning and Hamdani, 1997). This is especially important because MNEs are looking for locational advantages and are continuously examining how they can operate their production processes more efficiently (Dunning, 2002; UNCTAD, 1998, 2001).

Second, FDI should be seen as a means and not an end in itself. The way forward for most developing countries is not only to intensify their move toward a more efficient IPR regime, but also intensify their technological R \& D (Asid et al., 2004) to maximize their growth potential. Clearly, the bigger challenge is not just how to attract FDI, but more importantly, how to utilize it in generating the growth that is so much needed to reduce poverty. It must be noted that FDI's growth enhancing effect is possible only when it stimulates domestic capacity of the host country. Consequently, policymakers seeking to strengthen their IPR system must also emphasize FDI that generates externalities to the local economy.

Third, the review of the literature illustrates that where developing countries move to address weaknesses in their IPR system, they tend to experience enhanced access to technology through FDI and licensing (Park and Lippoldt, 2003, 2005). However, an important component of any program to attract high-quality FDI and promote technology transfer is the development of a competent indigenous technological capacity. As noted by Maskus (2000b), developing countries can benefit from IPR reform by developing policies to promote competitive markets, but eve more importantly, enhance their capacity to use IPR. Developing countries would 
therefore need to invest in education and training, which will help to enhance the absorptive capacity of domestic firms to utilize technology from the developed countries to improve their productivity.

In discussing the results of the study, it is worth mentioning a few of its limitations. First, the study examined the effect of IPR on the total volume of FDI and not its composition and hence the study's findings are limited to the extent that IPR has differential effects on sectoral composition of FDI. Second, both country-specific and regional factors influence the effect of IPRs on FDI, and therefore more regional and country-specific studies should be done to validate the findings of this study. As noted by Lesser (2002), determinate results of the effect of IPR on FDI may only be possible on a country - by - country basis. The inconsistency in most of the results reported also suggests that quantitative methods will need to be supplemented with qualitative methods to better understand how IPR affect FDI inflows.

The evidence of this study indicates that, at the least, developing countries benefited from strengthening their IPR through increased inflow of FDI. Consequently, while it is true that lower IPR in the context of developing countries facilitate imitation of foreign technologies, developing countries can also strengthen their IPR in order to increase FDI and technology transfer to facilitate the innovative capabilities of its citizens and domestic firms. As the study's results show, owners of technology of intellectual property rights place the issue of intellectual property protection high on their list of factors that would influence their decision as to where to invest. It can therefore be argued that if developing countries establish strong IPR regimes supported by measures aimed at improving the investment climate, communications infrastructure, and human resources capacity, they are likely to benefit from an increased flow of the right type of FDI essential for stimulating economic growth.

\section{References}

Asid, R. Yusof, Y. S. and Saiman, S. (2004). Impact of intellectual property protection, domestic market condition and R \& D expenditure on foreign direct investment Inflow. Preliminary Evidence in Elected Cross-Countries Data. Munich Personal RePEc Archive Paper No. 1008.

Asiedu, Elizabeth. (2002). "On the determinants of foreign direct investment to developing countries: Is Africa different? World Development, 30(1): 107-119.

Braga, P. A. and Fink, C. (1998), "The relationship between intellectual property rights and foreign direct investment”, Duke Journal of Comparative and International Law, 19, pp.163-187.

Chakrabarti, A. (2001). "The determinants of foreign direct investment. Kyklos, 54, 89-114.

Commission on Intellectual Property Rights (2002). Integrating intellectual property rights and development policy. London.

Dunning, J. (1993). Multinational Enterprises and the Global Economy, Wokingham: Addison -Wesley.

Dunning, John H. (2002). Determinants of foreign direct investment: Globalization induced changes and the role of FDI policies. Background paper for the Annual Bank Conference on Development Economics, Oslo.

Dunning, John H. and Hamdani, Khalil A. (Eds.). (1997). The new globalism and developing countries. New York: United Nations University Press.

Dunning, John H. (1981). International production and the multinational enterprise. London: Allen and Unwin.

Falvey, R., Foster, N. and Greenaway, D. (2006). "Intellectual Property Rights and Economic Growth," Review of Development Economics, 10(4): 700-719.

Ginarte, J. C. and Park, W. (1997). "Determinants of Patent Rights: A cross - national study", Research Policy, 26, pp. 283-301.

Global Development Finance. (2005). Financial flows to developing countries: Recent trends and near-term prospects. Washington, DC: World Bank.

Global Development Network Growth Database. http://www.nyu.edu. Accessed on 04/01/2007.

Kalande, Christopher M. (2002). "Intellectual property, foreign direct investment and the least -developed countries", Journal of World Intellectual Property, 5, 1, pp.11-128.

Kenny, C. and Keremane, R. (2007). "Toward universal telephone access. Market progress and progress beyond the market. Telecommunications Policy, 31, pp. 155-163

Kobrin, S. (2005). "The determinants of liberalization of FDI policy in developing countries: A cross-sectional analysis, 1991-2001”, Transnational Corporations, 14, 1, pp. 67-103.

Kondo, E. (1995). "The Effect of Patent Protection on foreign direct investment", Journal of World Trade, 29, 6, pp.97-122. 
Lee, J and Mansfield, E. (1996). "Intellectual property protection and US foreign direct Investment", Review of Economics and Statistics, 78, pp. 181-186.

Leger, A. (2006). "Intellectual Property Rights and Innovation in developing Countries: Evidence from Panel Data", Proceedings of the German Development Economics Conference, Berlin.

Lesser, W. (2002). "The Effects of intellectual property rights on foreign direct investment and imports in developing countries", IP Strategy Today No. 4, pp. 1-16.

Lippoldt, D. (2006). Intellectual property rights, pharmaceuticals and foreign direct investment. Group d'Economie Mondale de Sciences Po. Policy Brief 2006. Paris.

Makki, S. and Somwaru, A. (2004). "Impact of foreign direct investment and trade on economic growth: evidence from developing countries," American Journal of Agricultural Economics, 86(3), pp. 795-801.

Mansfield, E. (1994). Intellectual property protection, foreign direct investment, and Technology Transfer. World Bank and International Finance Corporation, Washington, DC.

Maskus, E. K. (1998). "The Role of intellectual property rights in encouraging foreign direct investment and technology transfer", Duke Journal of International Law, 9, pp. 109 - 161.

Maskus, Keith. E (2000a). Intellectual property rights in the global economy. Washington, DC: Institute of International Economics.

Maskus, K. E. (2000b). Intellectual property rights and foreign direct investment. CIES Policy Discussion Paper 0022 .

Morisett, Jacques. (2000). Foreign direct investment in Africa. Policies also matter World Bank Policy Research Working Paper 2481. Washington, DC: World Bank.

Naude, W. A. and Krugell, W.F. (2003). Investigating the determinants of foreign direct investment in Africa using panel data. NEPAD Council's International Trade and Investment Conference on Promoting Inter - and Intra - Regional Trade in Africa, 25-27 May, East London,- South Africa.

Nganga, P. K. (2005). Determinants and Effects of Foreign Direct Investment in Developing Nations: A Theoretical and Empirical Analysis. PhD Dissertation, Southern Illinois University, Carbondale.

Nicholson, M. W. (2002). Intellectual property rights and international technology transfer. The impact of industry characteristics. US Federal Trade Commission Manuscript.

Nicholson, M. W. (2007). "The impact of industry characteristics and IPR policy on foreign direct investment", Review of World Economics, 43(1), pp. 27-54.

Nunnenkamp, Peter. (2002). Determinants of FDI in developing countries: Has globalization changed the rules of the game? (Working paper 1122). Kiel, Germany: Kiel Institute for the World Economy.

Nunnenkamp, P. and Spatz, J. (2003). Intellectual property rights and foreign direct investment: The role of industry and host country characteristics. Kiel Institute for World Economics Working Paper No. 1167.

Park, G. W. and Lippoldt, D. (2003). The impact of trade-related intellectual property rights on trade and foreign direct investment in developing countries. Working Party of the Trade Committee, OECD TD/TC/WP (2002).

Park, G. W. and Lippoldt, D. (2005). "International Licensing and Strengthening of Intellectual Property Rights in Developing Countries During the 1990s", OECD Economic Studies, 40, pp. $7-42$.

Political Risk Services Group. (2006). International Country Risk Guide. East Syracuse, New York.

Seyoum, B. (1996). "The impact of intellectual property rights on foreign direct investment", Columbia Journal of World Business, 31, 1, pp.50-59.

Seyoum, B. (2006). "Patent protection and foreign direct investment. Thunderbird International Business Review, 48(3), pp. 389-404.

Smarzynska, B. J. (2004). "The composition of foreign direct investment and protection of intellectual property rights: evidence from transition economies", European Economic Review, 48, pp. 39-62.

Smith, P. M. (2001). "How do patent rights affect U.S exports, affiliates, sales, and licenses? Journal of International Economics, 55, pp. 411-439.

United Nations Conference on Trade and Development. (1998). World investment report, 1998: Trends and determinants. New York: United Nations.

United Nations Conference on Trade and Development. (2001). International Arrangements for Transfer of Technology. Outcome of the expert meting. New York: United Nations. 
United Nations Conference on Trade and Development. (2005). World investment Report 2005: Transnational corporations and the internationalization of $R \& D$. New York United Nations.

United Nations Conference on Trade and Development. (2006). World Investment Report 2006: FDI from Developing and Transition Economies: Implications for Development. New York: United Nations.

United Nations Conference on Trade and Development (UNCTYAD). (2003). Investment Policy Review: Botswana. New York: United Nations.

World Economic Outlook (WEO) Database September 2000. http://www.imf.org Accessed on 04/04/2006.

World Development Report. (2004). World Development Indicators. Washington, DC: World BankWorld Bank (2006), World Development Indicators. Washington, DC: World Bank.

Table 1. Average FDI and Patent Protection Index (1985-2003).

\begin{tabular}{|c|c|c|c|c|c|}
\hline Country & IPR & FDI & Country & IPR & FDI \\
\hline Algeria & 3.42 & 0.54 & Liberia & 2.98 & 2.52 \\
\hline Angola & 0.86 & 8.90 & Madagascar & 0.63 & 2.07 \\
\hline Argentina & 2.60 & 1.88 & Malawi & 0.59 & 3.32 \\
\hline Bangladesh & 2.28 & 0.13 & Malaysia & 4.15 & 3.02 \\
\hline Benin & 2.86 & 1.77 & Mali & 1.69 & 2.74 \\
\hline Bolivia & 2.17 & 4.49 & Mauritania & 3.18 & 2.74 \\
\hline Botswana & 1.99 & 1.69 & Mauritius & 1.11 & 3.01 \\
\hline Brazil & 2.18 & 1.88 & Mexico & 2.11 & 2.19 \\
\hline Burkina $\mathrm{F}$ & 2.40 & 0.28 & Morocco & 1.96 & 2.50 \\
\hline Burundi & 2.94 & 0.16 & Mozambique & 3.19 & 0.00 \\
\hline Cameroon & 2.65 & 0.48 & Nepal & 0.07 & 2.69 \\
\hline Central African Rep & 2.65 & 0.25 & Nicaragua & 2.15 & 1.09 \\
\hline Chad & 2.80 & 8.67 & Niger & 0.52 & 2.57 \\
\hline Chile & 2.82 & 4.56 & Nigeria & 3.36 & 3.13 \\
\hline Colombia & 1.98 & 2.13 & Pakistan & 11.95 & 1.99 \\
\hline Congo & 2.69 & 4.43 & panama & 2.68 & 2.88 \\
\hline Congo DR & 2.86 & 0.48 & Papua New Guinea & 3.31 & 0.00 \\
\hline Costa Rica & 1.79 & 2.83 & Paraguay & 1.20 & 2.30 \\
\hline Cote d'Ivoire & 2.69 & 1.31 & Peru & 2.18 & 1.87 \\
\hline Dom Rep & 2.61 & 2.76 & Philippines & 1.56 & 2.67 \\
\hline Ecuador & 2.11 & 2.95 & Rwanda & 0.37 & 2.89 \\
\hline Egypt & 2.11 & 1.58 & Senegal & 0.97 & 2.74 \\
\hline El Salvador & 2.73 & 1.20 & Sierra Leone & -0.55 & 2.64 \\
\hline Ethiopia & 0.25 & 0.82 & South Africa & 0.76 & 3.69 \\
\hline Fiji & 2.10 & 2.17 & Sri Lanka & 1.03 & 3.24 \\
\hline Gabon & -0.32 & 2.81 & Sudan & 1.44 & 3.52 \\
\hline Ghana & 1.38 & 3.02 & Swaziland & 5.72 & 2.52 \\
\hline Grenada & 8.07 & 1.91 & Syria & 2.36 & 2.58 \\
\hline Guatemala & 1.20 & 1.20 & Tanzania & 1.69 & 2.90 \\
\hline Guyana & 7.71 & 1.54 & Thailand & 2.10 & 1.88 \\
\hline Haiti & 0.19 & 3.23 & Togo & 1.61 & 2.57 \\
\hline Honduras & 2.01 & 2.05 & Tunisia & 2.13 & 1.99 \\
\hline India & 0.38 & 1.70 & Uganda & 1.55 & 2.74 \\
\hline Indonesia & 0.25 & 1.04 & Uruguay & 0.79 & 2.55 \\
\hline Iran & 0.06 & 2.17 & Venezuela & 2.05 & 2.13 \\
\hline Jamaica & 3.55 & 2.72 & Zambia & 3.45 & 3.52 \\
\hline Jordan & 1.60 & 2.22 & Zimbabwe & 0.98 & 2.99 \\
\hline Kenya & 0.37 & 2.64 & & & \\
\hline
\end{tabular}


Table 2. Summary of Sub - Periods FDI and IPR

$\begin{array}{ccc}\text { Period } & \text { IPR } & \text { FDI } \\ 1985-1989 & 2.14 & 1.00 \\ 1990-1994 & 2.14 & 0.68 \\ 1995-1999 & 2.43 & 2.88 \\ 2000-2003 & 2.84 & 3.16\end{array}$

Table 3. Intellectual Property Rights and Foreign Direct Investment Regressions

\begin{tabular}{|c|c|c|c|c|c|}
\hline & 1 & 2 & 3 & 4 & 5 \\
\hline ARG & $\begin{array}{l}0.078^{* * *} \\
(0.01)\end{array}$ & $\begin{array}{l}0.078^{* * *} \\
(0.011)\end{array}$ & $\begin{array}{l}0.071^{* * *} \\
(0.013)\end{array}$ & $\begin{array}{l}0.068^{* * *} \\
(0.012)\end{array}$ & $\begin{array}{c}0.050^{* *} \\
(0.023)\end{array}$ \\
\hline OPEN & $\begin{array}{l}0.011 * * \\
(0.004)\end{array}$ & $\begin{array}{l}0.009 * * * \\
(0 . .004)\end{array}$ & $\begin{array}{l}0.011 * * * \\
(0 . .004)\end{array}$ & $\begin{array}{l}0.011 * * * \\
(0 . .004)\end{array}$ & $\begin{array}{c}0.011^{* *} \\
(0 . .005)\end{array}$ \\
\hline INF & $\begin{array}{r}0.000 \\
(0.000)\end{array}$ & $\begin{array}{r}0.000 \\
(0.000)\end{array}$ & $\begin{array}{r}0.000 \\
(0.000)\end{array}$ & $\begin{array}{r}0.000 \\
(0.000)\end{array}$ & $\begin{array}{r}0.000 \\
(0.000)\end{array}$ \\
\hline LPOP & $\begin{array}{r}0.000 \\
(0.080)\end{array}$ & $\begin{array}{r}0.000 \\
(0.000)\end{array}$ & $\begin{array}{r}0.000 \\
(0.000) \\
\end{array}$ & $\begin{array}{r}0.000 \\
(0.000) \\
\end{array}$ & $\begin{array}{r}0.000 \\
(0.000) \\
\end{array}$ \\
\hline RETURN & $\begin{array}{l}2.507 * * \\
(11.000)\end{array}$ & $\begin{array}{r}8.448 \\
(10.543) \\
\end{array}$ & $\begin{array}{c}20.776 * \\
(10.790)\end{array}$ & $\begin{array}{c}20.751^{*} \\
(11.101)\end{array}$ & $\begin{array}{c}20.208^{*} \\
(10.779) \\
\end{array}$ \\
\hline RISK & $\begin{array}{l}0.043 * * * \\
(0.006)\end{array}$ & $\begin{array}{l}0.039^{* * *} \\
(0.006)\end{array}$ & $\begin{array}{l}0.045^{* * *} \\
(0.006)\end{array}$ & $\begin{array}{l}0.046^{* * *} \\
(0.007)\end{array}$ & $\begin{array}{l}0.040^{* * *} \\
(0.008)\end{array}$ \\
\hline TEL & & $\begin{array}{r}0.006 \\
(0.004) \\
\end{array}$ & $\begin{array}{l}-0.003 \\
(0.004) \\
\end{array}$ & $\begin{array}{l}-0.003 \\
(0.004) \\
\end{array}$ & $\begin{array}{l}-0.004 \\
(0.003)\end{array}$ \\
\hline IPR & & & $\begin{array}{l}1.011^{* * *} \\
(0.172)\end{array}$ & $\begin{array}{r}0.905 . \\
(0.716) \\
\end{array}$ & $\begin{array}{l}0.796^{* * *} \\
(0.190)\end{array}$ \\
\hline IPRSQ & & & & $\begin{array}{r}0.009 \\
(0.139) \\
\end{array}$ & \\
\hline IPR*TRIPS & & & & & $\begin{array}{c}0.126^{* *} \\
(0.057) \\
\end{array}$ \\
\hline Constant & $\begin{array}{c}0.231 * * * \\
(0 . .038)\end{array}$ & $\begin{array}{l}0.180^{* * *} \\
(0.055)\end{array}$ & $\begin{array}{r}0.056 \\
(0.068) \\
\end{array}$ & $\begin{array}{r}0.055 \\
(0.066) \\
\end{array}$ & $\begin{array}{r}0.027 \\
(0.094) \\
\end{array}$ \\
\hline $\mathrm{N}$ & 194 & 192 & 179 & 179 & 179 \\
\hline DW & 2.21 & 2.17 & 2.04 & 2.10 & 2.05 \\
\hline $\mathrm{R}^{2}$-adjusted & 0.42 & 0.42 & 0.40 & 0.38 & 0.36 \\
\hline
\end{tabular}

*Significant at the $10 \%$ level. ${ }^{* *}$ Significant at the $5 \%$ level. $* * *$ Significant at the $1 \%$ level 